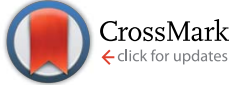

Cite this: RSC Adv., 2016, 6, 67540

\title{
Novel hydrogen- and halogen-bonding anion receptors based on 3-iodopyridinium units $\uparrow$
}

\author{
Valeria Amendola, ${ }^{\text {a }}$ Greta Bergamaschi, ${ }^{a}$ Massimo Boiocchi, $t^{\mathrm{b}}$ Nadia Fusco, ${ }^{\mathrm{a}}$

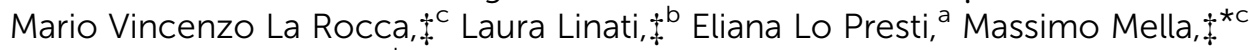 \\ Pierangelo Metrangolo*d and Ana Miljkovic ${ }^{a}$
}

Novel tripodal 3-iodopyridinium-based receptors were investigated through (i) UV-vis and NMR titrations with anions in solution, (ii) theoretical calculations, and (iii) X-ray diffraction studies. Their anion binding properties were compared to those of the monobranched model and/or non-halogenated model systems. Investigations in acetonitrile pointed out that the iodine atom in the meta position to pyridinium enhances anion affinity. According to computational studies, this effect seemed to depend on the electron-withdrawing nature of the iodine-substituents. Notably, $1: 1$ adducts were observed to form in solution with all the investigated anions. The strong de-shielding effect observed on the receptors' protons upon anion binding indicated their participation in hydrogen-bonds with the coordinated anion. This result was supported by theoretical calculations and, in the solid state, by X-ray diffraction studies on the complexes with nitrate and bromide. In the crystalline state, the pyridinium arms of the tripodal receptor assume a "2-up, 1-down" conformation. Both nitrate and bromide anions are included in the receptor's cavity, forming two hydrogen-bonding interactions with the protons of the "2-up" arms, and one halogen-bonding interaction with the $\mathrm{C}-\mathrm{I}$ group of a second molecular cation. The combination of hydrogen and halogen bonds leads to supramolecular chains in the crystals.

Received 6th June 2016
Accepted 11th July 2016

DOI: $10.1039 / c 6 r a 14703 \mathrm{~h}$

www.rsc.org/advances selective recognition of anionic species even in water. In the field of anion recognition, the importance of the so-called "nonconventional" HB interactions based on "weak" H-bond donors, e.g. nucleophilic aromatic $\mathrm{C}$ atoms, has also been recognized. ${ }^{4}$

Thanks to the pioneering work by Metrangolo and Resnati, another type of non-covalent interaction, i.e., halogen bonding, has become popular among supramolecular chemists, and in the last few years it has been having a significant impact on the supramolecular world. ${ }^{5}$

Halogen bonding (XB) was proved to have significant similarities with $\mathrm{HB}$, allowing to build sophisticated supramolecular architectures and functional materials, and leading to selective anion recognition in competing media, as shown by Beer ${ }^{6}$ and others. ${ }^{7} \mathrm{HB}$ and $\mathrm{XB}$ can be considered as the most relevant among non-covalent interactions. ${ }^{8,9}$ They both are characterised by high directionality and strong attraction, leading to contact distances shorter than the sum of the van der Waals radii of the involved atoms. For both $\mathrm{HB}$ and $\mathrm{XB}$, interaction involves an electrophilic species [i.e., $\mathrm{H}$ and $\mathrm{X}$ atoms for $\mathrm{HB}$ and $\mathrm{XB}$, respectively] and a nucleophilic atom therefore binding has a dominant electrostatic contribution. However, recent theoretical and experimental studies have shown that polarization, charge transfer, and dispersion forces also play an important role. ${ }^{10}$

Investigating a series of halopyridinium and haloanilinium salts, Rissanen ${ }^{11}$ pointed out how the balance between $\mathrm{HB}$ and 
$\mathrm{XB}$ is fundamental in determining the structure of these compounds in the solid state. This balance is also central in solution, and can be exploited in the design of anion receptors. The similar features of $\mathrm{HB}$ and XB have stimulated chemists to compare and contrast (supra)molecular systems based on either one or the other type of interactions, with a special regard to the field of anion recognition in solution. ${ }^{\mathbf{1 2}}$

In the last fifteen years, the research interests of our group in Pavia have been oriented towards the synthesis of selective anion receptors, containing positively charged and/or HB-donor fragments. ${ }^{13}$ Experience has taught us that stronger anion binding is obtained when several HB-donor groups converge towards the anionic guest, better if within a well-defined cavity. ${ }^{\mathbf{1 4}}$ Moreover, positive charges close to HB-donor groups in a receptor have a synergistic effect, thus increasing the interaction. As an example, the concave receptor containing three $9 H$ - $\beta$-carbolin-2-ium units strongly binds halide anions, thanks to the concerted efforts of the positive charges and the $\mathrm{H}$-donor groups of $9 \mathrm{H}$ - $\beta$-carbolin-2-ium. ${ }^{\mathbf{1 5 , 1 6}}$ Before us, Steed had observed similar effects in a series of 3-aminopyridinium based receptors. ${ }^{17}$ Steed also pointed out that, in the absence of the amino $\mathrm{N}-\mathrm{H}$ donor groups, the anion binding capabilities of these systems strongly decrease.

Our goal is now to move the filed forward by studying the synergic effect of positioning a number of positive charges, $\mathrm{XB}$ donors and non-classical HB donor groups (i.e. $\mathrm{C}-\mathrm{H}$ ) around the bowl-shaped cavity of a tripodal host. To do this, we synthesized new receptors, containing three 3-iodopyridinium arms appended to trialkylbenzene platforms, and we investigated their anion binding capabilities through NMR and UV-vis spectroscopies. We also compared our results to those obtained for the $N$-benzyl-3-iodopyridinium, as a model compound, and to those already available for analogous tripodal receptors based only on electrostatic and/or HB interactions. A computational study was carried out as a way to gauge the relative contribution provided by $\mathrm{HB}$ and $\mathrm{XB}$ to the stability of the complexes. For this purpose, isomeric "ion pair dissociation energies" (IPDE) and ${ }^{1} \mathrm{H}-\mathrm{NMR}$ chemical shifts were computed and helped us in rationalising the experimental titration results.

\section{Results and discussion}

The iodopyridinium-based receptors (see Scheme 1) were synthesized modifying a procedure, already applied by our group in the preparation of polypyridinium systems. ${ }^{15,16}$ Details are reported in ESI. $\uparrow$ The interaction with anions of all receptors was investigated by NMR and UV-vis experiments in organic solvents (acetonitrile, DMSO). Due to the low solubility of $2\left(\mathrm{PF}_{6}\right)_{3}$ and $3\left(\mathrm{PF}_{6}\right)_{3}$ in acetonitrile, NMR titrations on these two receptors were performed in DMSO/acetonitrile mixture.

\section{Single-branched pyridinium-based systems}

In the case of the model system $\mathbf{1} \mathbf{a}^{+}$, the formation constants of the $1: 1$ complexes with chloride, bromide, and iodide could be calculated from the fitting of the ${ }^{1} \mathrm{H}$-NMR titration data (see

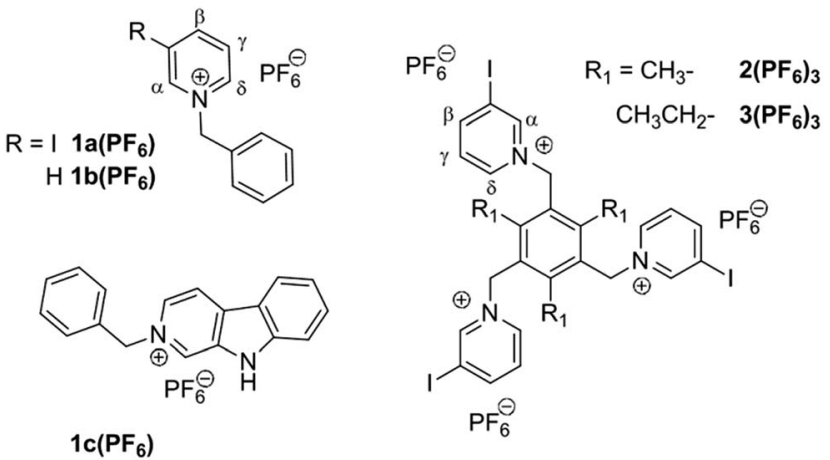

Scheme 1 Pyridinium-based anion receptors studied in this work.

Table 1 Affinity constants determined by ${ }^{1} \mathrm{H}-\mathrm{NMR}$ titrations with halides as TBA salts (in $\mathrm{CD}_{3} \mathrm{CN}, T=25^{\circ} \mathrm{C}$ )

\begin{tabular}{llll}
\hline Anion & $\log K_{11} / \mathbf{1} \mathbf{a}^{+}$ & $\log K_{11} / \mathbf{1} \mathbf{b}^{+}$ & $\log K_{11} / \mathbf{1} \mathbf{c}^{+b}$ \\
\hline $\mathrm{Cl}^{-}$ & $2.30(3)[2.27(1)]^{a}$ & $2.06(1)$ & {$[3.20(1)]^{a}$} \\
$\mathrm{Br}^{-}$ & $1.98(4)[2.08(1)]^{a}$ & n.d. & {$[2.48(1)]^{a}$} \\
$\mathrm{I}^{-}$ & $1.70(6)$ & n.d. & n.d.
\end{tabular}

${ }^{a}$ Constants obtained through UV-vis titrations in $\mathrm{CH}_{3} \mathrm{CN}\left(25^{\circ} \mathrm{C}\right)$. In parenthesis, the uncertainties on the last figures are reported. ${ }^{b}$ See ref. 14.

Table 1). Spectra and profiles are shown in the ESI (Fig. S1-S3†). ${ }^{1} \mathrm{H}-\mathrm{NMR}$ titrations with halides evidenced the preference of $\mathbf{1 a}^{+}$ for the chloride anion, followed by bromide and iodide (see Fig. 1). $\S$ This is not surprising, as it is the common trend observed in pyridinium systems.

Upon anion addition, protons in the ortho positions to the nitrogen, i.e. $\mathrm{H} \alpha$ and $\mathrm{H} \delta$, are the most affected. Therefore, the corresponding signals undergo a significant downfield shift, e.g. , $\Delta \delta=+0.53 \mathrm{ppm}$ and $+0.43 \mathrm{ppm}$ for $\mathrm{H} \alpha$ and $\mathrm{H} \delta$, respectively (see Fig. S1-S2 $\dagger$ ). Notably, also protons $\mathrm{H} \alpha$ in $\mathbf{1 b}^{+}$are deshielded even if to a lower extent $(+0.40 \mathrm{ppm}$ up to 20 eq. of chloride, see Fig. S3†). In principle, the iodopyridinium-based model compound 1a is capable of binding halide anions via different modes. XB is one, but also HB may be present, either in a mono- or bi-dentate fashion (Scheme 1 ). Anion $\cdots \pi$ interactions may also play a role. ${ }^{18}$ The observed downfield shifts are more indicative of $\mathrm{HB}$ rather than $\mathrm{XB}$, for which upfield shifts would be expected. ${ }^{19}$ However, disentangling the different contributions in solution is difficult as different binding modes may occur simultaneously. The binding constants of $\mathbf{1 a}^{+}$and $\mathbf{1 b}^{+}$, shown in Table 1 , point out that anion affinity is higher for $\mathbf{1 a}^{+}$than for the simple $N$-benzyl pyridinium analogue. We can thus conclude that the iodine-substituent has a positive effect on the anion binding capabilities of pyridinium receptors, as

$\S$ Noticeably, upon addition of TBAF to a solution of $1 \mathrm{a}\left(\mathrm{PF}_{6}\right)$ in $\mathrm{CD}_{3} \mathrm{CN}$, the disappearance of ${ }^{1} \mathrm{H}$-NMR signals of most aromatic protons was observed, thus suggesting the occurrence of fluoride-induced deprotonation/decomposition processes. $^{20}$ 


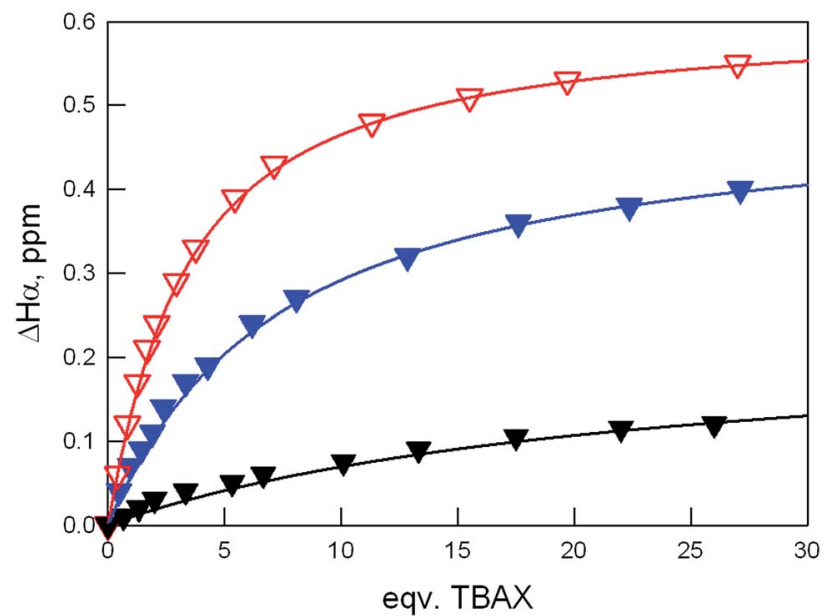

Fig. $1{ }^{1} \mathrm{H}-\mathrm{NMR}$ titrations of $1 \mathrm{a}^{+}$with halides in $\mathrm{CD}_{3} \mathrm{CN}$. Variation of the chemical shift of $\mathrm{H} \alpha$ upon anion (as TBA salt) addition (symbols: red, chloride; blue, bromide; black, iodide). The experimental profiles are superimposed to the formation curves of the $1: 1$ adducts with the anions, calculated according to the constants reported in Table 1.

a likely consequence of its electron withdrawing effect on the pyridine hydrogen atoms.

The interaction of $\mathbf{1 a}^{+}$with chloride and bromide was also studied by UV-vis titrations in acetonitrile. The molecular cation displays a band at $290 \mathrm{~nm}\left(2.1 \times 10^{3} \mathrm{M}^{-1} \mathrm{~cm}^{-1}\right)$, attributable to a charge transfer that involves the iodine substituent. Upon anion addition, this band broadens. From the fitting of the profiles, the affinity constants for both chloride and bromide could be determined [2.27(1) and 2.08(1) log units, respectively], confirming the NMR titration results. Both UV-vis spectra and the distribution diagrams are shown in the ESI (see Fig. S4-S6†). Interestingly, the obtained affinity constants are lower than those determined in the same conditions by our group ${ }^{\mathbf{1 5}}$ for the $9 H$ - $\beta$-carbolin-2-ium system (see $\mathbf{1 c}^{+}$in Table 1 ). This suggests that the $\mathrm{NH}$ group in $9 H$ - $\beta$-carbolin-2-ium may have a stronger impact on the affinity towards anions than the iodinesubstitution in the studied pyridinium-based receptors.

To understand the origin of the higher anion affinity for $\mathbf{1 a}^{+}$ compared to $\mathbf{1 b}^{+}$, we computationally studied the two model systems in presence of $\mathrm{Cl}^{-}$and $\mathrm{Br}^{-}$. Several low-lying solution conformers were optimized. The corresponding IPDE values are within $1.8 \mathrm{kcal} \mathrm{mol}^{-1}$ (see Table 2), although the conformers show different "modes of interaction" with the anion (see Fig. 2 and $\mathrm{S} 7, \dagger$ for $\mathbf{1 a}^{+}$and $\mathbf{1} \mathbf{b}^{+}$with $\mathrm{Cl}^{-}$, respectively).

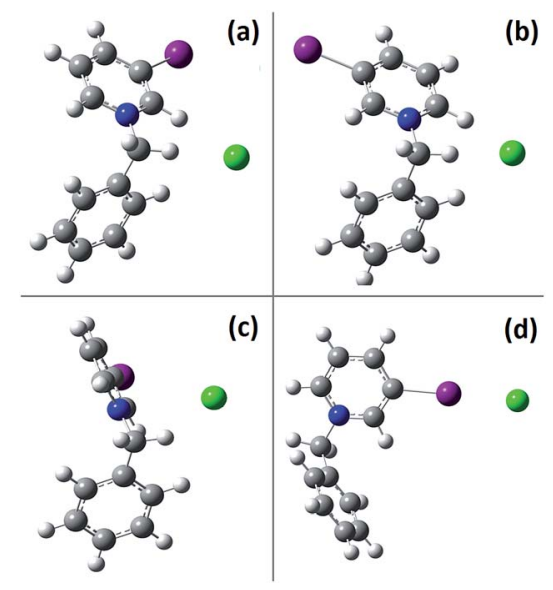

Fig. 2 Geometries of four possible conformers for the binding of $\mathrm{Cl}^{-}$ by 1 .

Regardless, the computational results strongly support the experimental data as far as the relative stability of the complexes is concerned (see also Fig. $\mathrm{S} 8 \dagger$ for $\mathbf{1 c}^{+} / \mathrm{Cl}^{-}$), even if this may be due to entropic effects due to the lower population of low lying isomers as in the iodide case. Our theoretical results suggest, in fact, that the halogen-bonded species (d) shown in Fig. 2 lies at least $0.9 \mathrm{kcal} \mathrm{mol}^{-1}$ above the other stable conformers found for $\mathbf{1 a}^{+} / \mathrm{Cl}^{-}$and $\mathbf{1 a}^{+} / \mathrm{Br}^{-}$(i.e., Fig. 2(a) and (c), respectively), and has a lower IPDE, which indicate that it is not the most relevant species occurring in solution. Interestingly, the structures shown in Fig. 2 and $\mathrm{S} 7 \dagger$ also fully support the NMR assignments presented in Fig. S1-S3, † justifying the incremental shifts of the hydrogen atoms involved in the interaction with the anions. Chemical shifts computed at the B3LYP/6-31+G(d,p)/GIAO level, in fact, suggest that $\mathrm{H} \alpha, \mathrm{H} \delta$ and the methylene protons should all be substantially shifted downfield $(\Delta \delta=1.0-3.3 \mathrm{ppm})$ for the species shown in Fig. 2(a) and (b). On the other hand, $H \beta$ and $\mathrm{H} \gamma$ should remain mostly unchanged. Only minor shifts are instead predicted for the X-bonding species [i.e., Fig. 2(d)].

As for the size of the computed chemical shifts, these appear larger than the experimental data. Such apparent discrepancy can be readily rationalized, considering that the measured shifts represent the average of all possible structures accessible within the time scale of the NMR measurement. In this respect, the small energy differences reported in Table 2 suggest that the ion pairs are highly fluxional, so that the structures in Fig. 2 and $\mathrm{S} 7 \dagger$ represent only limiting cases. This is corroborated by the energy profiles shown in Fig. S9. $\dagger$ The fluxionality also explains

Table 2 Ion pair dissociation energies, IPDE $=E\left(S^{+} / X^{-}\right)-E\left(S^{+}\right)-\left(X^{-}\right)$, where $S^{+}$is the pyridinium cation and $X^{-}$is the anion. Solvent effects are introduced via the PCM model. The letters refer to the isomers shown in Fig. 2 for $1 \mathrm{a}^{+}$, and in Fig. S7 for $1 \mathrm{~b}^{+}$. Counterpoise corrected energies are given in the ESI

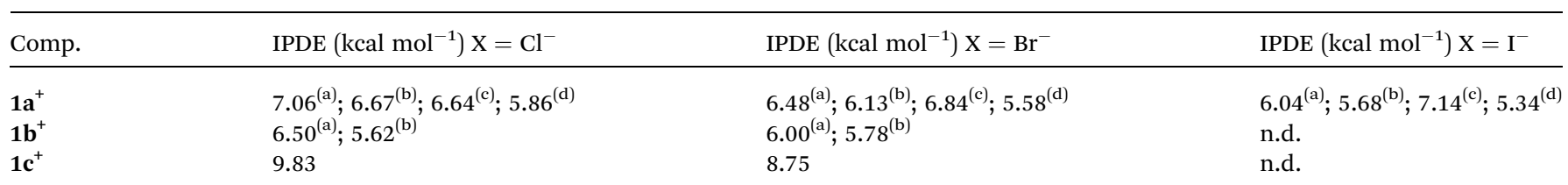


the presence in the NMR spectrum of a singlet for $\mathrm{CH}_{2}$, instead of the double doublet expected on symmetry considerations (i.e., the symmetry-breaking induced by the interaction with the anion). Albeit lower in magnitude, Counterpoise corrected IPDE (see $\mathrm{ESI} \dagger$ ) support our conclusions.

By slow diffusion of diethyl ether into acetonitrile solutions of $1 \mathbf{a}\left(\mathrm{PF}_{6}\right)$, in both the absence and presence of TBAI, single crystals suitable for X-ray diffraction analysis were obtained. In the solid state, for both $1 \mathrm{a}\left(\mathrm{PF}_{6}\right)$ and $\mathbf{1 a}(\mathrm{I})$, the coexistence of $\mathrm{HB}$ and $\mathrm{XB}$ interactions could be observed. In the case of $\mathbf{1 a}\left(\mathrm{PF}_{6}\right)$, the interactions between the molecular cation $\mathbf{1 a}^{+}$and the $\mathrm{PF}_{6}{ }^{-}$ anion are weak (see Tables 3 and 4 , and the ESI for details $\dagger$ ).

On the other hand, significant XB interactions could be detected in 1a(I), where two similar but not symmetrically equivalent $\mathbf{1 a}^{+}$molecular cations interact with the same $\mathrm{I}^{-}$ion via two $\mathrm{C}-\mathrm{I} \cdots \mathrm{I}^{-}$halogen bonds (Fig. 3). In particular, the $\mathrm{I}^{\cdots} \mathrm{I}^{-}$ distances [i.e., 3.541(1) and 3.575(2) $\AA$, see Table 4] were much shorter than the value of $4.18 \AA$, obtained by summing the van der Waals radius of iodine $(1.98 \AA)^{20}$ and the ionic radius of iodide $(2.20 \AA) .{ }^{21}$ The normalized $R$ parameters [defined as the ratio between the observed $\mathrm{I} \cdots \mathrm{I}^{-}$separation and the sum of the proper radii of the involved species] are 0.85 for both interactions, thus confirming the strength of the two halogen bonds. As further proof, the two $\mathrm{C}-\mathrm{I} \cdots \mathrm{I}^{-}$angles are almost linear [178.4(3) and $171.1(3)^{\circ}$, respectively], the closest to $180^{\circ}$ corresponding to a well-established XB interaction (Table 4). Notably, similar features were found by Rissanen, ${ }^{\mathbf{1 0}}$ in the crystal structure of an ethanol-clathrate hydrate crystal, containing two independent $\mathbf{1 a}^{+}$molecular cations interacting with a chloride anion. In that case, two short halogen bonds were observed, involving the C-I XB-donor groups of two $\mathbf{1 a}^{+}$molecular cations and two independent $\mathrm{Cl}^{-}$anions. The calculated $R$ values, 0.83 and 0.85 , as well as the observed $\mathrm{C}-\mathrm{I} \cdots \mathrm{Cl}^{-}$angles, 174.1(1) and 174.6(1) $)^{\circ}$, are similar to those measured in our system.

In the 1a(I) crystal, weak $\mathrm{HB}$ interactions could also be observed. The shortest $\mathrm{C}-\mathrm{H} \cdots \mathrm{I}^{-}$distances involve two $\mathrm{C}-\mathrm{H}$ bonds of the iodopyridinium moiety and two $\mathrm{I}^{-}$anions [i.e. 3.72(1) and 3.77(1) A, see Table 3]. These separations are shorter than $3.90 \AA$, obtained by summing the van der Waals radius of $\mathrm{C}$ $(1.70 \AA)^{20}$ and the ionic radius of $\mathrm{I}^{-}(2.20 \AA){ }^{21}$

\section{Tripodal 3-iodopyridinium-based receptors}

Bowl-shaped positively charged systems, such as those obtained by appending three pyridinium groups to a tris(alkyl) benzene scaffold, are known to form stable complexes with anions in acetonitrile solution. Studies performed by Steed, ${ }^{\mathbf{1 7}}$ and independently by our group, ${ }^{\mathbf{1 5 , 1 6}}$ demonstrated that anion affinity is strongly influenced by (i) the receptor preorganisation imparted by the alkyl chains on the platform, and depends on (ii) the presence of HB donor groups on the pyridinium arms.

In order to shed light on how appending XB-donor groups on pyridinium-based tripodal receptors affects their anion binding capabilities, we synthesised $2\left(\mathrm{PF}_{6}\right)_{3}$ and $3\left(\mathrm{PF}_{6}\right)_{3}$. These molecular systems were obtained by reacting an excess of 3-iodopyridine with 1,3,5-tribromomethyl mesitylene and 1,3,5tribromomethyl-2,4,6-triethylbenzene, respectively (see ESI for details $\dagger$ ). The two chosen platforms are expected to exert a different degree of pre-organisation on the tripodal receptors, thus affecting anion affinity.

Table 3 Geometrical features for the $\mathrm{C}-\mathrm{H} \cdots \mathrm{A}$ hydrogen-bond interactions in the crystal structures of this work. The reported contacts have D ...A separations shorter than the sum of the van der Waals radii of the involved atom (ionic radii are used for $\mathrm{I}^{-}$and $\mathrm{Br}^{-}$). Symmetry code: $\left({ }^{\prime}\right)=-1$ $+x, 1 / 2-y,-1 / 2+z ;\left({ }^{\prime \prime}\right)=1+x, y, z ;\left({ }^{\prime \prime \prime}\right)-1+x, y, z$

\begin{tabular}{|c|c|c|c|c|c|}
\hline Comp. & D donor group & $\mathrm{H} \cdots \mathrm{A}(\AA)$ & $\mathrm{D} \cdots \mathrm{A}(\AA)$ & $\mathrm{D}-\mathrm{H} \cdots \mathrm{A}$ & A acceptor atom \\
\hline $\mathbf{1 a}\left(\mathrm{PF}_{6}\right)$ & $\mathrm{C}(3)-\mathrm{H}(3)$ & $2.526(5)$ & $3.133(9)$ & $123.2(5)$ & $\mathrm{F}(4)^{\prime}{ }_{\mathrm{FF}_{6}}^{-}$ \\
\hline $1 \mathrm{a}(\mathrm{I})$ & $\mathrm{C}(15)-\mathrm{H}(15)$ & $3.326(13)$ & $3.773(13)$ & 112.0(9) & $\mathrm{I}(4)^{\prime \prime} \mathrm{I}^{-}$ \\
\hline $1 a(I)$ & $\mathrm{C}(17)-\mathrm{H}(17)$ & $3.221(12)$ & $3.719(12)$ & $115.7(9)$ & $\mathrm{I}(3)^{\prime \prime} \mathrm{I}^{-}$ \\
\hline $2\left(\mathrm{NO}_{3}\right)_{2}\left(\mathrm{PF}_{6}\right)$ & $\mathrm{C}(12)-\mathrm{H}(12)$ & $2.306(14)$ & $3.104(14)$ & 143.5(9) & $\mathrm{O}(4) \mathrm{a}^{\prime \prime \prime} \mathrm{NO}_{3}{ }^{-}$ \\
\hline $2\left(\mathrm{NO}_{3}\right)_{2}\left(\mathrm{PF}_{6}\right)$ & $\mathrm{C}(19)-\mathrm{H}(19)$ & $2.637(22)$ & $2.971(22)$ & $101.8(8)$ & $\mathrm{O}(6) \mathrm{a}^{\prime \prime \prime} \mathrm{NO}_{3}^{-}$ \\
\hline $2(\mathrm{Br})\left(\mathrm{PF}_{6}\right)_{2}$ & $\mathrm{C}(12)-\mathrm{H}(12)$ & $2.781(10)$ & $3.565(10)$ & $142.5(6)$ & $\operatorname{Br}(1)_{\mathrm{Br}^{-}}$ \\
\hline $2(\mathrm{Br})\left(\mathrm{PF}_{6}\right)_{2}$ & $\mathrm{C}(19)-\mathrm{H}(19)$ & $2.707(9)$ & $3.522(9)$ & $146.7(6)$ & $\operatorname{Br}(1)_{\mathrm{Br}^{-}}$ \\
\hline
\end{tabular}

Table 4 Geometrical features for the $\mathrm{C}-\mid \cdots Y$ halogen bonds in the crystal structures of this work. The normalized $R$ value is defined as: $d_{1} \ldots Y /\left(r_{1}+\right.$ $\left.r_{\mathrm{Y}}\right)$, with $r_{1}=1.98 \AA$ and $r_{\mathrm{Y}}=1.47 \AA$ for $\mathrm{F}_{\left[\mathrm{PF}_{6}\right]^{-}}, 1.52 \AA$ for $\mathrm{O}_{\left[\mathrm{NO}_{3}\right]^{-}}, 2.20 \AA$ for $\mathrm{I}_{1^{-}}, 1.96 \AA$ for $\mathrm{Br}_{\mathrm{Br}}$

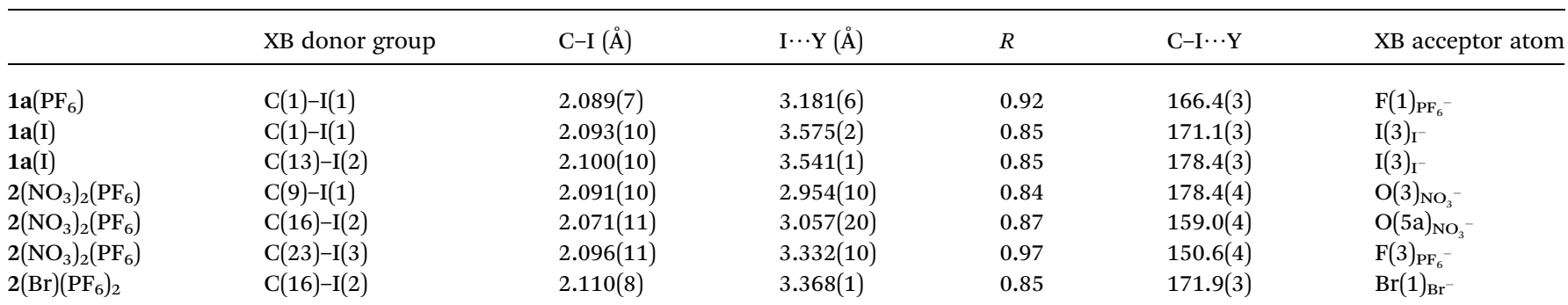




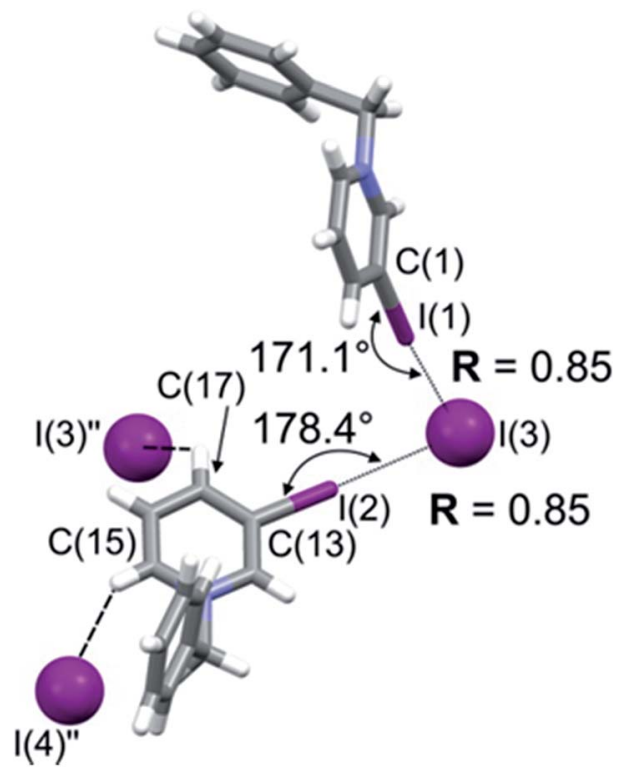

Fig. 3 A simplified sketch of the crystal structure of $1 a(I)$. Atom names are shown only for atoms involved in $\mathrm{C}-\mid \cdots Y$ halogen bonds (drawn with dotted lines) and weak $\mathrm{C}-\mathrm{H} \cdots \mathrm{A}$ hydrogen bonds (drawn with dashed lines). The normalized $R$ values $=d_{1 \ldots Y} /\left(r_{1}+r_{Y}\right)$ and the $C-\mid \cdots Y$ bond angles are reported. Symmetry code: $\left({ }^{\prime}\right)=-1+x, 1 / 2-y,-1 / 2+$ $z ;\left(^{\prime \prime}\right)=1+x, y, z$.

Anion binding studies were performed by UV-vis and NMR titrations both in pure acetonitrile and in the presence of $10 \%$ DMSO. Due to the low solubility of the receptors in $100 \%$ acetonitrile, UV-vis titrations were performed at $2.0 \times 10^{-5} \mathrm{M}$ concentration. Both $2^{3+}$ and $3^{3+}$ display an absorption band at about $295 \mathrm{~nm}$. Upon anion addition (as the TBA salt), an hyperchromic effect was observed (UV-vis spectra, profiles and the Job plot for chloride are available in the $\mathrm{ESI}^{\dagger}$ ).

The fitting of the titration profiles suggests the presence of a single equilibrium, leading to the formation of a $1: 1$ complex with all anions. The binding constants are shown in Table 5. The affinity trend is similar in the two receptors (i.e., $\mathrm{Cl}^{-} \gg \mathrm{Br}^{-}$ $>\mathrm{CH}_{3} \mathrm{COO}^{-}>\mathrm{HSO}_{4}{ }^{-}, \mathrm{NO}_{3}{ }^{-}>\mathrm{I}^{-}$). However, stronger binding was observed for $3^{3+}$ with spherical anions, $\mathrm{Cl}^{-}$and $\mathrm{Br}^{-}$in particular. This might be due to the higher pre-organisation imparted by triethyl arms to the bowl-shaped receptor, compared to the methyl groups of $2^{3+}$.

Table 5 Affinity constants determined through UV-vis titrations of $2^{3+}$ and $3^{3+}$ with anions (as the TBA salts) in $100 \% \mathrm{CH}_{3} \mathrm{CN}$

\begin{tabular}{lll}
\hline Anion & $\log K_{11} / 2^{3+}$ & $\log K_{11} / 3^{3+}$ \\
\hline $\mathrm{Cl}^{-}$ & $4.65(1)[3.70(2)]^{a}$ & $5.16(1)\left[4.07(2)^{a} ; 4.04(3)^{b}\right]$ \\
$\mathrm{Br}^{-}$ & $4.46(1)$ & $4.91(2)$ \\
$\mathrm{I}^{-}$ & $3.59(1)$ & $3.71(1)$ \\
$\mathrm{CH}_{3} \mathrm{COO}^{-}$ & $4.45(1)$ & $4.40(2)$ \\
$\mathrm{HSO}_{4}^{-}$ & $4.13(1)$ & $4.08(2)$
\end{tabular}

${ }^{a}$ In the presence of $10 \%$ DMSO $\left(25^{\circ} \mathrm{C}\right) .{ }^{b}$ Constants obtained through ${ }^{1} \mathrm{H}$-NMR titrations in $\mathrm{CD}_{3} \mathrm{CN} / \mathrm{d}^{6}$-DMSO mixture (10\% $\mathrm{d}^{6}$-DMSO). The uncertainties on the last figures are reported in parentheses.
In the case of chloride, UV-vis titrations were also performed in $\mathrm{CH}_{3} \mathrm{CN} / \mathrm{DMSO}$ (10\% DMSO) mixture. Notably, better solubility allowed us to work at higher concentrations $\left(2.0 \times 10^{-4}\right.$ M) than in pure acetonitrile. A general lower affinity was observed in the mixture as a consequence of the competing effect of DMSO on anion binding. However, these experiments confirmed the formation of $1: 1$ complexes, with stronger binding capabilities for $3^{3+}$ (see Table 5) compared to $2^{3+}$.

Very interestingly, the affinity constants obtained for $3^{3+}$ in acetonitrile are significantly higher than those determined by Steed, for a tris(3-aminopyridinium) receptor based on the tris(ethyl)benzene scaffold $\left[\mathrm{Br}^{-}, \log K_{11}=4.14 ; \mathrm{CH}_{3} \mathrm{COO}^{-}, \log K_{11}\right.$ $=4.02] .{ }^{17}$ This result indicates that the iodine atom in the meta position of pyridinium has a stronger effect on anion binding than an amino (HB) group.

However, the very good anion binding properties of $3^{3+}$ are in turn exceeded by the $9 H$ - $\beta$-carbolin-2-ium based tripodal receptor, studied by our group some years ago. ${ }^{16}$ This trifurcate system, consisting of three $9 H$ - $\beta$-carbolin-2-ium arms appended to a mesitylene platform, showed association constants one/two order of magnitude higher [e.g. $\left.\mathrm{Br}^{-}, \log K_{11}=6.65\right]$ than those reported for both $2^{3+}$ and $3^{3+}$ in Table 5. As already mentioned for the mono-branched system $\mathbf{1 c}^{+}$, the high anion affinity observed for $9 H$ - $\beta$-carbolin-2-ium species has to be attributed to the acidity of the carbazole-like $\mathrm{NH}$ group, and to its good $\mathrm{HB}$ donor tendencies.

Further information on the interaction of $3^{3+}$ with anions in solution was obtained through the ${ }^{1} \mathrm{H}-\mathrm{NMR}$ titration with TBACl (see Fig. 4 and 5; the family of spectra is shown in the ESI $\dagger$ ). Protons $\mathrm{H} \delta$, in the para position to iodine, seem to be directly involved in the binding, undergoing a down-field shift of $\Delta \delta=$ $+0.70 \mathrm{ppm}$ upon chloride addition ( $v s .+0.43 \mathrm{ppm}$ for $\mathbf{1 a}^{+}$). Protons $\mathrm{H} \alpha$ are also affected, even if to a significantly lower extent $\left(\Delta \delta=+0.14 \mathrm{ppm}\right.$ for $3^{3+} v s .+0.54 \mathrm{ppm}$ for $\left.1 \mathrm{a}^{+}\right)$. The slight shielding of protons $\mathrm{H} \beta$ can be attributed to the increase of the electron density on the receptor framework upon anion binding. These results indicate that the interaction with the chloride anion mainly involves the ortho protons of pyridinium groups. Notably, in most examples in the literature and in the mono-branched compound $\mathbf{1 a}^{+}$, the ortho-protons are the most

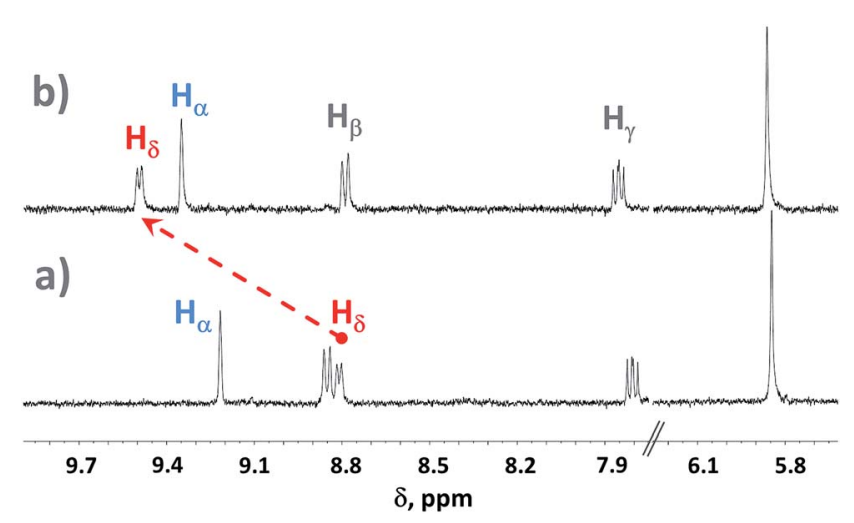

Fig. $4{ }^{1} \mathrm{H}$-NMR spectra of $3^{3+}$ in $\mathrm{CD}_{3} \mathrm{CN} / \mathrm{d}^{6}$-DMSO mixture $\left(10 \% \mathrm{~d}^{6}\right.$ DMSO), taken before (a) and after addition of excess TBACl (b). The family of spectra is shown in the ESI. $\dagger$ 


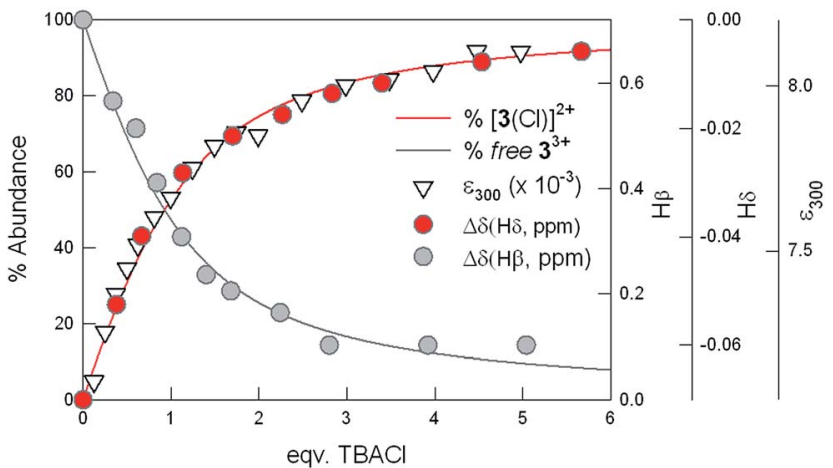

Fig. $5{ }^{1} \mathrm{H}-\mathrm{NMR}$ and UV-vis profiles for the titration of $3^{3+}$ with TBACl in acetonitrile/DMSO mixture. The distribution diagram was obtained, by considering a $1: 1$ binding constant of $4.04 \mathrm{log}$ units (see Table 5). For details see the text; further material is available in ESI (see Fig. S15† for the family of ${ }^{1} \mathrm{H}$ NMR spectra).

affected by anion binding, due to the direct participation of $\mathrm{C}-\mathrm{H}$ bonds in the interaction (as HB-donor groups)..$^{15,16}$ By treating the experimental data obtained through UV-vis and ${ }^{1} \mathrm{H}-\mathrm{NMR}$ titrations, we could determine the affinity constants reported in Table 5. The distribution diagram of the species, with the superimposed titration profiles, is shown in Fig. 5. A good correspondence of the results obtained by the two techniques can be observed.

The interpretation of the experimental data is fully supported by the theoretical analysis of the $2^{3+} / \mathrm{Cl}^{-}$or $2^{3+} / \mathrm{Br}^{-}$ complexes (Table 6). As in the case of $\mathbf{1 a}^{+}$, various conformers can be formed. Their structures differ in the relative position of the pyridinium groups with respect to the plane of the phenyl ring ("3-up" or "2-up, 1-down"). Differences are also observed in the position of the $\mathrm{H} \alpha$ and $\mathrm{H} \delta$ atoms pointing towards the anion. The four lowest lying species with $\mathrm{Cl}^{-}$are shown in Fig. 6; these low energy conformers are all within $3.7 \mathrm{kcal} \mathrm{mol}^{-1}$, a slightly wider interval than the one seen in the case of $\mathbf{1 a}^{+}$. Notably, the substitution of $\mathrm{H} \delta$ with $\mathrm{H} \alpha$ (belonging to the same pyridinium ring) in the interaction with $\mathrm{Cl}^{-}$raises the energy by $0.8 \mathrm{kcal} \mathrm{mol}^{-1}$ for the "3-up" isomer, its two conformers (in Fig. 6(a) and (b)) being the most stable species in solution.

As the population of the remaining two species (Fig. 6(c) and (d)) is expected to be low, the energy data rationalize the smaller change in the chemical shift of $\mathrm{H} \alpha$ observed upon NMR titration with chloride (see Fig. 4). The Counterpoise correction supports this conclusion (see ESI $\dagger$ ).

The slow diffusion of diethyl ether into acetonitrile solutions of $2\left(\mathrm{PF}_{6}\right)_{3}$ in the presence of nitrate and bromide (as the TBA

Table 6 lonic pair dissociation energies. IDPE $=E\left(S^{+} / X^{-}\right)-E\left(S^{+}\right)-$ $\left(X^{-}\right)$, where $S^{+}$is the ligand molecule and $X^{-}$is the anion. All the energies take into account the effect of appropriate solvent via SCRF models. Letters refer to the conformer labels in Fig. 6. Counterpoise corrected energies for the complexes are given in the ESI

\begin{tabular}{lll}
\hline Comp. & IPDE $\left(\mathrm{kcal} \mathrm{mol}^{-1}\right) \mathrm{X}=\mathrm{Cl}^{-}$ & IPDE $\left(\mathrm{kcal} \mathrm{mol}^{-1}\right) \mathrm{X}=\mathrm{Br}^{-}$ \\
\hline $\mathbf{2}^{3+}$ & $8.34^{(\mathrm{a})} ; 7.55^{(\mathrm{b})} ; 6.05^{(\mathrm{c})} ; 5.67^{(\mathrm{d})}$ & $9.05^{(\mathrm{a})} ; 8.97^{(\mathrm{d})}$
\end{tabular}

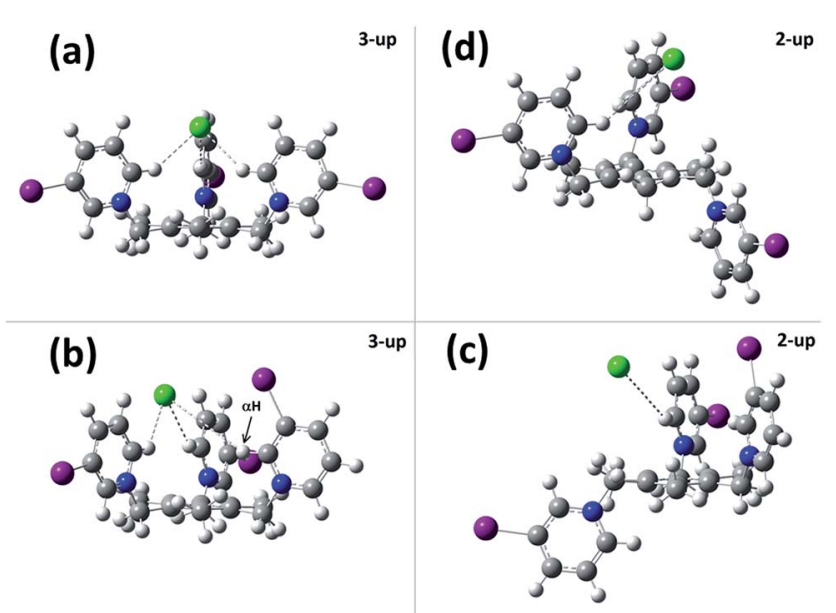

Fig. 6 Lowest conformers for $2^{3+} / \mathrm{Cl}^{-}$. Note that top and bottom conformers differ due to the rotation of an iodo-pyridinium group in the up position around the $\mathrm{CH}_{2}-\mathrm{N}$ bond. Such rotation substitutes $\mathrm{H} \alpha$ to $\mathrm{H} \delta$ in the contact with the anion.

salts) allowed us to isolate crystals of $2\left(\mathrm{NO}_{3}\right)_{2}\left(\mathrm{PF}_{6}\right)$ and $2(\mathrm{Br})\left(\mathrm{PF}_{6}\right)_{2}$ salts suitable for X-ray diffraction studies.

The conformation of the $2^{3+}$ molecular cation, as well as the arrangement of $\mathrm{HB}$ and XB interactions, are very similar in the nitrate and bromide salts (compare Fig. 7 and S16 ${ }^{\dagger}$ ). In both crystals, one of the three iodopyridinium arms is turned out of the receptor's cavity, and it is placed on the other side of the trimethylbenzene's plane (i.e., "anti" conformation). Such a "2up, 1-down" conformation has already been reported by Steed for other tripodal pyridinium-based systems in the solid state. ${ }^{\mathbf{1 7}}$ Notably, it also corresponds to one of the low energy conformers obtained for this receptor in the theoretical calculations.

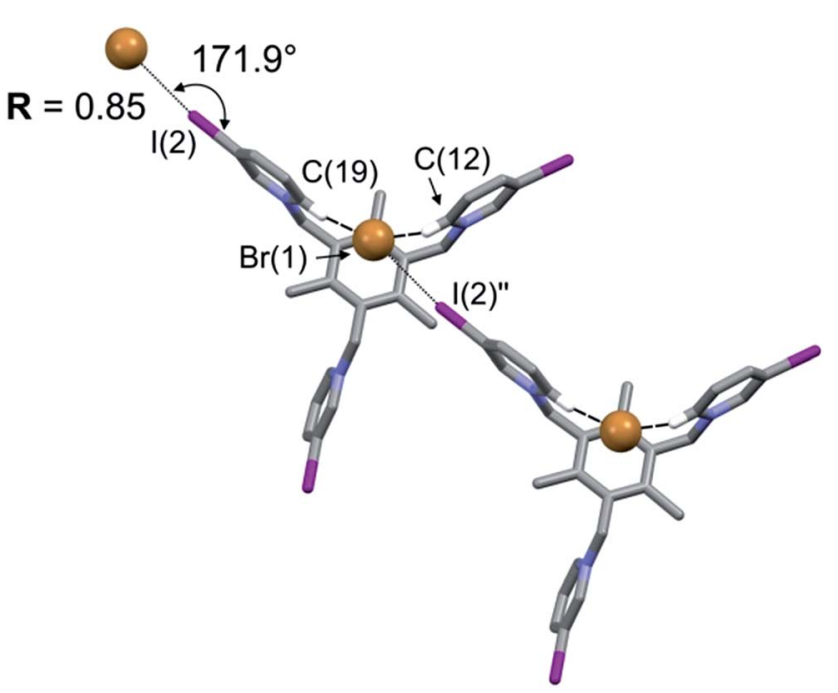

Fig. 7 A simplified sketch of the crystal structure of $2(\mathrm{Br})\left(\mathrm{PF}_{6}\right)_{2}\left(\mathrm{PF}_{6}{ }^{-}\right.$ counter ions are not shown for simplicity). Names are shown only for atoms involved in $\mathrm{C}-1 \cdots \mathrm{Y}$ halogen bonds (drawn with dotted lines) and $\mathrm{C}-\mathrm{H} \cdots \mathrm{A}$ hydrogen bonds (drawn with dashed lines). The normalized $R$ values $=d_{1} \ldots Y /\left(r_{1}+r_{Y}\right)$ and the $C-\mid \cdots Y$ bond angles are reported. Symmetry code: (") $x,-1+y, z ;\left({ }^{\prime \prime \prime}\right)-1+x, y, z$. 
The presence of ethyl substituents on the platform, such as in $3^{3+}$, is expected to enhance the receptor's preorganization, thus forcing the pyridinium arms to point in the same direction. Unfortunately, all attempts to obtain single crystals suitable for diffraction studies have been unsuccessful.

In the crystal structure of $2(\mathrm{Br})\left(\mathrm{PF}_{6}\right)_{2}$, all the iodine atoms are oriented out of the receptor's cavity, probably to comply with steric requirements. On the other hand, the two $\mathrm{C}-\mathrm{H}$ bonds in the para position to the iodine atoms, belonging to the "2-up" arms, point towards the centre of the cavity and interact with the bromide ion through HB interactions. Notably, the involved $\mathrm{H}$ atoms correspond to $\mathrm{H} \delta$ protons in the NMR titration.

The bromide anion is located almost above the centre of the trimethylbenzene ring, and profits of a XB interaction with the C-I group of a second $2^{3+}$ cation (see Fig. 7). In the solid, the combination of these $\mathrm{HB}$ and $\mathrm{XB}$ interactions gives origin to supramolecular chains in both $2\left(\mathrm{NO}_{3}\right)_{2}\left(\mathrm{PF}_{6}\right)$ and $2(\mathrm{Br})\left(\mathrm{PF}_{6}\right)_{2}$ crystals. Geometrical features are reported in Tables 3 and 4 ; details on the crystal structure of $2\left(\mathrm{NO}_{3}\right)_{2}\left(\mathrm{PF}_{6}\right)$ are available in the ESI. $\dagger$

\section{Conclusions}

In this work, 3-iodo-pyridinium units in tripodal systems have been used for the first time to selectively bind anions in competing media (e.g., acetonitrile with 10\% DMSO). Thanks to 3-iodopyridinium, tripodal cavities were obtained in which different types of interactions cooperate in the binding of the included anionic guest: (i) electrostatic forces; (ii) halogenbonding and (iii) non-conventional hydrogen bonding interactions (i.e. with the receptor's $\mathrm{C}-\mathrm{H}$ donor groups). Our studies in solution through UV-vis and NMR titrations pointed out that iodine atoms effectively enhance the anion binding tendencies of our pyridinium-based systems. Computational investigations on the model compound $\mathbf{1 a}^{+}$suggested that this finding may depend more on the electron withdrawing effect of iodine [on the coordinating pyridyl hydrogens] rather than on the occurrence of relevant halogen bonding in solution. However, this latter interaction dominates the binding of anions in the solid state.

In the case of the tripodal receptors, stable $1: 1$ inclusion complexes were obtained in solution for all the investigated anions. X-ray diffraction studies on $2\left(\mathrm{NO}_{3}\right)_{2}\left(\mathrm{PF}_{6}\right)$ and $2(\mathrm{Br})\left(\mathrm{PF}_{6}\right)_{2}$ disclosed that the pyridinium arms assume a "2-up, 1-down" conformation with respect to the mesitylene platform. In both adducts the anion lies within the receptor's cavity, forming (i) two H-bonding interactions with the $\mathrm{C}-\mathrm{H} \delta$ protons of the "2-up" arms, and (ii) one halogen-bonding interaction with the $\mathrm{C}-\mathrm{I}$ group of a second $2^{3+}$ cation. This combination of halogen- and hydrogen-bonds (i.e. with iodine atoms and $\mathrm{C}-\mathrm{H}$ groups, respectively) leads to the formation of supramolecular chains in the crystals of both $2\left(\mathrm{NO}_{3}\right)_{2}\left(\mathrm{PF}_{6}\right)$ and $2(\mathrm{Br})\left(\mathrm{PF}_{6}\right)_{2}$.

Notably, in the endo-coordination of the included anion, $\mathrm{HB}$ interactions are preferred over XBs. This may depend on the fact that all of the iodine atoms are oriented out of the cavity, due to steric congestion.
In conclusion, the combination of multiple interactions within a single receptor brought about strong anion binding in solution, even in a competing medium. Moreover, this also led to an unexpected outcome: the formation of supramolecular chains in the crystals. The results exposed herein represent a significant advance in the field of anion recognition based on $\mathrm{HB}$ and $\mathrm{XB}$, provide valuable tips for those working in the field and encourage researchers to continue along this path, i.e. using multiple and diverse interactions within receptor cavities in order to obtain a higher selectivity.

\section{Experimental}

\section{Materials and methods}

All reagents for syntheses were purchased from Sigma-Aldrich and used without further purification. All reactions were performed under dinitrogen. Mass spectra were acquired on a Thermo Finnigan ion trap LCQ Advantage Max instrument equipped with an ESI source. ${ }^{1} \mathrm{H}$ - and ${ }^{13} \mathrm{C}$-NMR spectra were recorded on a Bruker ADVANCE 400 spectrometer (operating at 9.37 T, $400 \mathrm{MHz}$ ). UV-vis spectra were run on a Varian Cary 50 SCAN spectrophotometer, with quartz cuvettes of the appropriate path length $(1$ or $0.1 \mathrm{~cm})$ at $25.0 \pm 0.1{ }^{\circ} \mathrm{C}$ under inert conditions. Solvents were dried by common methods. Solvents were dried by common methods. Syntheses are reported in the ESI $; \dagger \mathbf{1} \mathbf{b}\left(\mathrm{PF}_{6}\right)$ was prepared according to a known procedure. ${ }^{22}$ The experimental procedures of NMR and UV-vis titrations have been described elsewhere. ${ }^{23}$ Titration data were processed with the Hyperquad package ${ }^{24}$ to determine the equilibrium constants.

\section{Crystal structure analysis}

Diffraction data for $1 \mathrm{a}\left(\mathrm{PF}_{6}\right)$ (colourless, $0.43 \times 0.28 \times 0.07$ $\mathrm{mm}^{3}$ ) and 1a(I) (pale yellow, $0.45 \times 0.14 \times 0.08 \mathrm{~mm}^{3}$ ) crystals were collected by means of an Enraf-Nonius CAD4 four circle diffractometer, whereas diffraction data for $2\left(\mathrm{NO}_{3}\right)_{2}\left(\mathrm{PF}_{6}\right)$ (colourless, $\left.0.23 \times 0.07 \times 0.05 \mathrm{~mm}^{3}\right)$ and $2(\mathrm{Br})\left(\mathrm{PF}_{6}\right)_{2}$ (colourless, $\left.0.17 \times 0.10 \times 0.08 \mathrm{~mm}^{3}\right)$ crystals were collected on a Bruker-AXS diffractometer equipped with the SMART-APEX CCD detector. Both instruments work at room temperature with $\mathrm{Mo}_{\mathrm{K} \alpha} \mathrm{X}$ radiation $(\lambda=0.71073 \AA)$.

Crystal data were reported on Table 7. Data reductions (including intensity integration, background, Lorentz and polarization corrections) for intensities collected with the conventional diffractometer were performed with the WinGX package; ${ }^{25}$ absorption effects were evaluated with the psi-scan method $^{26}$ and absorption correction was applied to the data. Frames collected by the CCD-based system were processed with the SAINT software ${ }^{27}$ and intensities were corrected for Lorentz and polarization effects; absorption effects were empirically evaluated by the SADABS software ${ }^{28}$ and absorption correction was applied to the data. All crystal structures were solved by direct methods (SIR 97) ${ }^{29}$ and refined by full-matrix leastsquares procedures on $F^{2}$ using all reflections (SHELXL2014). ${ }^{30}$ Anisotropic displacement parameters were used for all non-hydrogen atoms. Hydrogens have been placed at calculated 
Table 7 Crystal data for the studied compounds

\begin{tabular}{|c|c|c|c|c|}
\hline & $1 a\left(\mathrm{PF}_{6}\right)$ & $1 \mathrm{a}(\mathrm{I})$ & $2\left(\mathrm{NO}_{3}\right)_{2}\left(\mathrm{PF}_{6}\right)$ & $2(\mathrm{Br})\left(\mathrm{PF}_{6}\right)_{2}$ \\
\hline Formula & $\mathrm{C}_{12} \mathrm{H}_{11} \mathrm{~F}_{6} \mathrm{INP}$ & $\mathrm{C}_{24} \mathrm{H}_{22} \mathrm{I}_{4} \mathrm{~N}_{2}$ & $\mathrm{C}_{27} \mathrm{H}_{27} \mathrm{~F}_{6} \mathrm{I}_{3} \mathrm{~N}_{5} \mathrm{O}_{6} \mathrm{P}$ & $\mathrm{C}_{27} \mathrm{H}_{27} \mathrm{BrF}_{12} \mathrm{I}_{3} \mathrm{~N}_{3} \mathrm{P}_{2}$ \\
\hline$M$ & 441.09 & 846.04 & 1043.21 & 1144.06 \\
\hline Space group & $P 2_{1} / c$ (no. 14$)$ & $P c 2_{1} b$ (no. 29$)$ & $P \overline{1}($ no. 2$)$ & $C 2 / c$ (no. 15$)$ \\
\hline$a[\AA]$ & $10.256(1)$ & $7.526(3)$ & $11.352(2)$ & $24.163(2)$ \\
\hline$b[\AA]$ & $9.723(2)$ & $11.789(4)$ & $13.844(3)$ & $11.441(1)$ \\
\hline$\beta\left[^{\circ}\right]$ & $96.674(9)$ & 90 & $101.442(4)$ & $97.977(1)$ \\
\hline$\gamma\left[^{\circ}\right]$ & 90 & 90 & $99.631(4)$ & 90 \\
\hline$V\left[\AA^{3}\right]$ & $1513.8(3)$ & $2740.1(15)$ & $1856.0(7)$ & $7545.1(10)$ \\
\hline$z$ & 4 & 4 & 2 & 8 \\
\hline$\rho_{\text {calcd }}\left[\mathrm{g} \mathrm{cm}^{-3}\right]$ & 1.935 & 2.051 & 1.867 & 2.014 \\
\hline$\mu \mathrm{Mo}_{\mathrm{K} \alpha}\left[\mathrm{mm}^{-1}\right]$ & 2.276 & 4.562 & 2.643 & 3.713 \\
\hline$R_{\text {int }}$ & 0.0189 & 0.0338 & 0.0386 & 0.0447 \\
\hline Strong data ${ }^{a}$ & 2298 & 3387 & 4891 & 4435 \\
\hline Refined param. & 190 & 271 & 469 & 436 \\
\hline$R_{1}, \mathrm{w}_{2}{ }^{\mathrm{I}}$ & $0.0604,0.1314$ & $0.0323,0.0630$ & $0.0730,0.2343$ & $0.0651,0.1877$ \\
\hline$R_{1}, \mathrm{w} R_{2}^{b}$ & $0.0874,0.1538$ & $0.0403,0.0677$ & $0.0926,0.2561$ & $0.0920,0.2127$ \\
\hline GOF & 1.088 & 1.081 & 1.071 & 1.064 \\
\hline 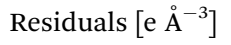 & $0.53,-0.72$ & $0.68,-0.51$ & $1.60,-1.14$ & $1.95,-1.35$ \\
\hline
\end{tabular}

positions and their positions refined according to a riding model.

Positional disorder affected a nitrate counter ion in the $2\left(\mathrm{NO}_{3}\right)_{2}\left(\mathrm{PF}_{6}\right)$ crystal and the $\mathrm{NO}_{3}{ }^{-}$anion resulted placed over two alternative positions half populated. The X-ray diffraction quality of the $2\left(\mathrm{NO}_{3}\right)_{2}\left(\mathrm{PF}_{6}\right)$ crystal did not allow a full unconstrained structure refinement and the geometries of the disordered nitrate counter ions, as well as those of the hexafluorophosphate ion, were restrained to the expected ones using soft DFIX and DANG restraints.

CCDC 1476623-1476626 contain the supplementary crystallographic data for this paper. $\dagger$

\section{Computational details}

All calculations were carried out with the Gaussian 09 package. $^{31}$ Conformation analysis and geometry optimizations were carried out at the MP2 level for complex $1 \mathbf{a}^{+} / \mathrm{X}^{-}, \mathbf{1} \mathbf{b}^{+} / \mathrm{X}^{-}$and $1 \mathbf{c}^{+} / \mathrm{X}^{-}$. For the complex $2^{3+} / \mathrm{X}^{-}$, structural optimizations were carried out using the B3LYP functional due to the larger species size. ${ }^{32}$ MP2 single point energies were subsequently obtained employing the B3LYP geometries. A polarized/augmented double zeta basis set $(6-31+G(d, p)$ for light atoms and he LANL2DZ basis set augmented with the diffuse function from the aug-cc-pVDZ set for the halogen atoms) was used in all the calculations; effectivecore potentials (LANL) were also used for $\mathrm{Cl}, \mathrm{Br}$, and I to reduce computational costs. Solvent effects were evaluated using the PCM model and different solvents were selected in order to reproduce the experimental conditions. ${ }^{33}$ Basis set superposition errors were estimated via the Counterpoise approach at the MP2 level in all cases. The calculation of chemical shifts for the hydrogen atoms was carried out employing the GIAO procedure as implemented in Gaussian 09. ${ }^{34}$

\section{Acknowledgements}

MIUR-PRIN 2011 "Integrated supramolecular technologies for chemical information processing: advanced molecular devices and materials (InfoChem)".

\section{Notes and references}

1 (a) N. Busschaert, C. Caltagirone, W. Van Rossom and P. Gale, Chem. Rev., 2015, 115(15), 8038-8155; (b) P. Gale and C. Caltagirone, Chem. Soc. Rev., 2015, 44(13), 42124227; (c) M. Giese, M. Albrecht and K. Rissanen, Chem. Rev., 2015, 115(16), 8867-8895; (d) V. Blazek Bregovic, N. Basaric and K. Mlinaric-Majerski, Coord. Chem. Rev., 2015, 295, 80-124; (e) I. Saha, J. T. Lee and C.-H. Lee, Eur. J. Org. Chem., 2015, 18, 3859-3885; $(f)$ R. B. P. Elmes and K. A. Jolliffe, Chem. Commun., 2015, 51(24), 4951-4968; $(g)$ K.-C. Chang, S.-S. Sun, M. O. Odago and A. J. Lees, Coord. Chem. Rev., 2015, 284, 111-123.

2 (a) E. Graf and J. M. Lehn, J. Am. Chem. Soc., 1976, 98(20), 6403-6405; (b) J. M. Lehn, Acc. Chem. Res., 1978, 11(2), 49-57.

3 (a) Anion Receptor Chemistry, ed. J. L. Sessler, P. A. Gale and W.-S. Cho, RSC Publishing, 2006; (b) Anion Coordination 
Chemistry, ed. K. Bowman-James, A. Bianchi and E. GarcíaEspana, John Wiley \& Sons, New York, 2012.

4 J. Cai and J. L. Sessler, Chem. Soc. Rev., 2014, 43, 6198-6213. 5 (a) P. Metrangolo, H. Neukirch, T. Pilati and G. Resnati, Acc. Chem. Res., 2005, 38(5), 386-395; (b) P. Metrangolo, F. Meyer, T. Pilati, G. Resnati and G. Terraneo, Angew. Chem., Int. Ed., 2008, 47(33), 6114-6127; (c) G. Cavallo, P. Metrangolo, T. Pilati, G. Resnati, M. Sansotera and G. Terraneo, Chem. Soc. Rev., 2010, 39(10), 3772-3783; (d) G. Cavallo, P. Metrangolo, R. Milani, T. Pilati, A. Priimagi, G. Resnati and G. Terraneo, Chem. Rev., 2016, 116(4), 2478-2601.

6 (a) M. J. Langton and P. D. Beer, Acc. Chem. Res., 2014, 47(7), 1935-1949; (b) G. T. Spence and P. D. Beer, Acc. Chem. Res., 2013, 46(2), 571-586; (c) L. C. Gilday, S. W. Robinson, T. A. Barendt, M. J. Langton, B. R. Mullaney and P. D. Beer, Chem. Rev., 2015, 115(15), 7118-7195; (d) M. J. Langton, C. J. Serpell and P. D. Beer, Angew. Chem., Int. Ed., 2016, 55(6), 1974-1987.

7 (a) M. G. Chudzinski, C. A. McClary and M. S. Taylor, J. Am. Chem. Soc., 2011, 133, 10559-10567; (b) S. M. Walter, F. Kniep, L. Rout, F. P. Schmidtchen, E. Herdtweck and S. M. Huber, J. Am. Chem. Soc., 2012, 134(20), 8507-8512; (c) A. Vargas Jentzsch, A. Hennig, J. Mareda and S. Matile, Acc. Chem. Res., 2013, 46(12), 2791-2800; (d) B. Schulze and U. S. Schubert, Chem. Soc. Rev., 2014, 43(8), 2522-2571; (e) R. Tepper, B. Schulze, M. Jaeger, C. Friebe, D. Scharf, H. Goerls and U. S. Schubert, J. Org. Chem., 2015, 80(6), 3139-3150; $(f)$ S. Chakraborty, R. Dutta and P. Ghosh, Chem. Commun., 2015, 51(79), 14793-14796; $(g)$ H. Takezawa, T. Murase, G. Resnati, P. Metrangolo and M. Fujita, Angew. Chem., Int. Ed., 2015, 54, 8411-8414.

8 G. A. Jeffrey and W. Saenger, Hydrogen Bonding in Biological Structures, Springer-Verlag, Berlin, 1991, and references cited therein.

9 (a) G. Cavallo, P. Metrangolo, T. Pilati, G. Resnati and G. Terraneo, Cryst. Growth Des., 2014, 14(6), 2697-2702; (b) G. R. Desiraju, P. S. Ho, L. Kloo, A. C. Legon, R. Marquardt, P. Metrangolo, P. Politzer, G. Resnati and K. Rissanen, Pure Appl. Chem., 2013, 85, 1711-1713.

10 (a) A. Karpfen, Struct. Bonding, 2008, 126, 1-15; (b) M. Fourmigue, Curr. Opin. Solid State Mater. Sci., 2009, 13(3/4), 36-45; (c) B. Nepal and S. Scheiner, J. Phys. Chem. A, 2015, 119(52), 13064-13073; (d) H. Wang, W. Wang and W. J. Jin, Chem. Rev., 2016, 116(9), 5072-5104.

11 K. Raatikainen, M. Cametti and K. Rissanen, Beilstein J. Org. Chem., 2010, 6(4), 1-13.

12 (a) S. P. Cornes, C. H. Davies, D. Blyghton, M. R. Sambrook and P. D. Beer, Org. Biomol. Chem., 2015, 13, 2582-2587; (b) J. M. Mercurio, A. Caballero, J. Cookson and P. D. Beer, RSC Adv., 2015, 5, 9298-9306.

13 (a) V. Amendola, L. Fabbrizzi and E. Monzani, Chem.-Eur. J., 2004, 10, 76-82; (b) V. Amendola, M. Bonizzoni, D. EstebanGomez, L. Fabbrizzi, M. Licchelli, F. Sancenon and A. Taglietti, Coord. Chem. Rev., 2006, 250, 1451-1470; (c) V. Amendola, D. Esteban-Gomez, L. Fabbrizzi and M. Licchelli, Acc. Chem. Res., 2006, 39(5), 343-353; (d) G. Alibrandi, V. Amendola, G. Bergamaschi, L. Fabbrizzi and M. Licchelli, Org. Biomol. Chem., 2015, 13(12), 35103524 .

14 (a) V. Amendola, G. Alberti, G. Bergamaschi, R. Biesuz, M. Boiocchi, S. Ferrito and F.-P. Schmidtchen, Eur. J. Inorg. Chem., 2012, 21, 3410-3417; (b) R. Alberto, G. Bergamaschi, H. Braband, T. Fox and V. Amendola, Angew. Chem., Int. Ed., 2012, 51(39), 9772-9776.

15 V. Amendola, M. Boiocchi, L. Fabbrizzi and A. Palchetti, Chem.-Eur. J., 2005, 11, 120-127.

16 V. Amendola, M. Boiocchi, L. Fabbrizzi and A. Palchetti, Chem.-Eur. J., 2005, 11, 5648-5660.

17 K. J. Wallace, W. J. Belcher, D. R. Turner, K. F. Syed and J. W. Steed, Chem.-Eur. J., 2005, 11, 5648-5660.

18 P. Hay and R. Custelcean, Cryst. Growth Des., 2009, 9, 25392545.

19 M. Cametti, K. Raatikainen, P. Metrangolo, T. Pilati, G. Terraneo and G. Resnati, Org. Biomol. Chem., 2012, 10, 1329.

20 A. Bondi, J. Phys. Chem., 1964, 68, 441-451.

21 R. D. Shannon, Acta Crystallogr., 1976, A32, 751-767.

22 V. H. Vu, L.-A. Jouanno, A. Cheignon, T. Roisnel, V. Dorcet, S. Sinbandhit and J.-P. Hurvois, Eur. J. Org. Chem., 2013, 5464-5474.

23 G. Bergamaschi, M. Boiocchi, E. Monzani and V. Amendola, Org. Biomol. Chem., 2011, 9, 8276-8283.

24 P. Gans, A. Sabatini and A. Vacca, Talanta, 1996, 43, 17391753.

25 L. J. Farrugia, J. Appl. Crystallogr., 1999, 32, 837-838.

26 A. C. T. North, D. C. Phillips and F. S. Mathews, Acta Crystallogr., Sect. A: Found. Crystallogr., 1968, 24, 351-359.

27 Bruker, SAINT Software Reference Manual. Version 6, Bruker AXS Inc., Madison, Wisconsin, USA, 2003.

28 L. Krause, R. Herbst-Irmer, G. M. Sheldrick and D. Stalkeand, J. Appl. Crystallogr., 2015, 48, 3-10.

29 A. Altomare, M. C. Burla, M. Camalli, G. L. Cascarano, C. Giacovazzo, A. Guagliardi, A. G. Moliterni, G. Polidori and R. J. Spagna, J. Appl. Crystallogr., 1999, 32, 115-119.

30 G. M. Sheldrick, Acta Crystallogr., Sect. A: Found. Crystallogr., 2008, 64, 112-122.

31 M. J. Frisch, G. W. Trucks, H. B. Schlegel, G. E. Scuseria, M. A. Robb, J. R. Cheeseman, G. Scalmani, V. Barone, B. Mennucci, G. A. Petersson, H. Nakatsuji, M. Caricato, X. Li, H. P. Hratchian, A. F. Izmaylov, J. Bloino, G. Zheng, J. L. Sonnenberg, M. Hada, M. Ehara, K. Toyota, R. Fukuda, J. Hasegawa, M. Ishida, T. Nakajima, Y. Honda, O. Kitao, H. Nakai, T. Vreven, J. A. Montgomery Jr, J. E. Peralta, F. Ogliaro, M. Bearpark, J. J. Heyd, E. Brothers, K. N. Kudin, V. N. Staroverov, R. Kobayashi, J. Normand, K. Raghavachari, A. Rendell, J. C. Burant, S. S. Iyengar, J. Tomasi, M. Cossi, N. Rega, J. M. Millam, M. Klene, J. E. Knox, J. B. Cross, V. Bakken, C. Adamo, J. Jaramillo, R. Gomperts, R. E. Stratmann, O. Yazyev, A. J. Austin, R. Cammi, C. Pomelli, J. W. Ochterski, R. L. Martin, K. Morokuma, V. G. Zakrzewski, G. A. Voth, P. Salvador, J. J. Dannenberg, S. Dapprich, A. D. Daniels, Ö. Farkas, J. B. Foresman, J. V. Ortiz, J. Cioslowski and 
D. J. Fox, Gaussian 09, Revision B.01, Gaussian, Inc., Wallingford CT, 2009.

32 (a) A. D. Becke, J. Chem. Phys., 1993, 98(7), 5648-5652; (b) C. Lee, W. Yang and R. G. Parr, Phys. Rev. B, 1998, 37, 785789; (c) S. H. Vosko, L. Wilk and M. Nusair, Can. J. Phys., 1980, 58, 1200-1211; (d) P. J. Stephens, F. J. Devlin,
C. F. Chabalowski and M. J. Frisch, J. Phys. Chem., 1994, 98, 11623-11627.

33 M. Cossi, N. Rega, G. Scalmani and V. Barone, J. Comput. Chem., 2003, 24(6), 669-681, PCM.

34 (a) R. Ditchfield, Mol. Phys., 1974, 27(4), 789-807; (b) K. Wolinski, J. F. Hilton and P. Pulay, J. Am. Chem. Soc., 1990, 1s12(23), 8251-8260. 